\title{
JAVANIZATION IN STUDENT CITY: FINDING AND PRIORITIZING IDEA TO MAINTAIN LOCAL LANGUAGE IN INDONESIA
}

\author{
Zakka Ugih Rizqi*, Rizky Wulan Cahyaningtyas, Dhianitya Yogiari \\ Department of Industrial Engineering, Universitas Islam Indonesia \\ *ugihzakka@gmail.com
}

\begin{abstract}
The local language is one of the cultural properties that must be maintained. However, modernization can not be avoided and it causes the young generation to do not care about their own local language anymore. In Indonesia, there are already 11 extinct local languages. If there is no action to take care, it will increase the number of local language extinction. The Javanese language is one of local languages that is the most speakers in Indonesia, especially in Yogyakarta as the student city. However, the Javanese language itself is started to be left alone by the young generation. Therefore, this research is intended to give the scientific written idea to maintain Javanese language in Yogyakarta. This research is done by 2 steps of research, the first step is finding the idea by observation, literature study, and Focus Group Discussion with 3 experts. Second, prioritizing ideas to be realized using AHP with multi-expert. The result shows that there are 3 ideas that have to be realized sequentially. The first idea to be applied is 'One day with Javanese language program', second is the making of 'Java café', and the third is the selection of 'Javanese language ambassador'.
\end{abstract}

Keywords: AHP, Javanese, Written Idea, Focus Group Discussion

Received 17 February 2020 Accepted 05 April 2020

\section{INTRODUCTION}

Language is main tool to communicate in life, individual or social collective [1]. It is also said by Chaer and Agustina [2] and Soeparno [3] that main function of language is a communication tool that can be understood by each other. According to Aminuddin [4], language is a system that represents arbitrarily that uses a society to make interaction and self identify. It makes language as something that has important value so human can interact one to each other.

Every region has their own local language to communicate. It is the residence's responsibility to maintain their local language. In Indonesia, there are 652 local languages [5]. The government has listed there are 11 local languages that met their extinction, those languages come from Maluku, Papua, and East Nusa Tenggara [6]. Therefore, it is important to maintain local language to avoid extinction that melt away Indonesian culture property.

One of local languages that has a lot of speakers is Javanese language, in amount 84.300 .000 by year 2000 [7]. The amount of speakers is $50 \%$ of the total Indonesian and it is a language that has strong literary tradition and also high quality. It is also the crystallization of Javanese culture as a part of Indonesian culture [8]. So do the Javanese language, especially in Yogyakarta, javanese language is also the main language besides Indonesian language. As student city, Yogyakarta always be the main choice to go study. The label of student city makes Yogyakarta as the chosen place to study not only by Indonesian but also foreigner.

Unfortunately, there are lots of people who come from outside of Yogyakarta, especially students that go back to their places can not speak Javanese language correctly even had been living for years in Yogyakarta. This suits well based on Makarim in Sucahyo [9] that among his friends that speaks Krama Javanese is only 20-25\% because parents usually communicate 
with their children using Indonesian. In addition, according to the data from Kompas [10] it is known that in the last 5 years, the average grade of students in Yogyakarta for Javanese is only about 6 out of 10, meanwhile English can be up to 9 out of 10. Whereas, the ability of Javanese is very important to be owed by students because it can shape the character, ethics, and tolerance that is currently marginalized [11]. Meanwhile, in Bandung, many students can later speak Sundanese when they return back to their home regions. Or maybe in Eastern Asia, lets say Japan, almost all immigrants from outside Japan can later speak Japanese when they return back to their countries.

So, the purpose of this research is to give idea as an effort to maintain Javanese language in Yogyakarta. With this idea, some solutions are offered to make students from outside Yogyakarta, tourist, or the Yogyakarta society itself able to speak Javanese language correctly, and it will end up avoiding Javanese language from extinction. Besides giving solutions from the current problem, this research will also do prioritizing the alternative using AHP method.

\section{RESEARCH METHODS}

This research is done by 2 steps that will be explained below:

\section{Step 1: Finding Idea}

The direct observation is done first to know the current condition of Javanese language in Yogyakarta as well as the reason. It is done by doing an interview for 50 respondents randomly that meet the criteria: birth and grow in Yogyakarta (precisely Sleman), have the age between $20-30,50 \%$ are women and $50 \%$ are men, can speak (not dumb). After that, literature study is done to look for the current conditions seen from other perspectives (besides direct observation), factors that cause the decline of Javanese speakers, and the existing solutions to keep Javanese language from extinction. From those solutions, modification will be done to suit the solutions with current condition. The process will be done by doing FGD with 3 experts; 2 from cultural practitioner, and 1 from the government representation. The FGD process is carried out informally beginning with the elaboration of existing solutions, giving opinions from each expert, voting to determine the most feasible alternatives or ideas, and determining the criteria to be used in the next stage.

\section{Step 2: Prioritizing Idea}

From the ideas that have been made, not all of them can be realized at a time because of the limit of cost, resources, and time to realize all the ideas. Therefore, it needs the prioritizing process using criteria from FGD which is calculated using AHP method. AHP is a theory of decision making with multi-criteria that are formed in hierarchy [12]. Since the experts are more than 1, so it needs the geometric mean that will be calculated with Equation (1).

Where:

$$
a_{i j}=\left(z_{1} \times z_{2} \times z_{3} \times \ldots \times z_{n}\right)^{1 / n}
$$

$\mathrm{a}_{\mathrm{ij}} \quad=$ average of comparison between $\mathrm{Ai}$ and $\mathrm{Aj}$ for $\mathrm{n}$ expert

$\mathrm{Z}_{\mathrm{i}} \quad=$ average of comparison between criteria Ai to Aj expert-i

$\mathrm{n} \quad=$ number of experts

Some steps that will be done in AHP calculation process are: (1) Decomposition: This principle is used to detailing the problems so it will form a hierarchy structure that defines the objective, criteria, and alternative. (2) Comparative Judgement: Criteria and alternatives are judged by the pairwise comparison. According to Saaty [13] scale 1 to 9 is the best scale to express opinion. Value and definition of qualitative opinion from comparison scale by Saaty can be seen in Table 1. (3) Synthesis of Priority: After pairwise comparison matrix is founded, then find the eigen vector to get the local priority. Because of the pairwise matrix is conducted at any level, to get the global priority can be done by synthesis between local priority. (4) Logical Consistency: The purpose of calculating the consistency ratio is to see whether a value 
of consistency ratio is reaching $10 \%$ or not. The result will be valid if the consistency ratio $\leq$ $10 \%$ or $0.1[13]$.

Table 1. Scale of pairwase comparison

\begin{tabular}{cl}
\hline Rating & Two characteristics are equally important \\
3 & The preferred characteristics are slightly more important \\
5 & The preferred characteristics are moderately more important \\
7 & The preferred characteristics are strongly more important \\
9 & The preferred characteristics are absolutely more important \\
$2,4,6,8$ & Intermediate values between two characteristics that are very close to importance \\
Inverse aij = 1/ aij & $\begin{array}{l}\text { If activity i gets one number compared to activity } \mathrm{j} \text {, then } \mathrm{j} \text { has the inverse value } \\
\text { compared to } \mathrm{i}\end{array}$ \\
\hline
\end{tabular}

\section{FINDINGS AND DISCUSSION}

\section{Current Condition of Javanese Language}

Based on the results of observation, it shows that $66 \%$ of respondents can speak Javanese but are not fluent, $22 \%$ of them can not speak at all, and the remaining $12 \%$ fluently. Many of them think that speaking Indonesian and English is far more useful than Javanese and Javanese is considered not cool (tacky). This shows that the indigenous people of Yogyakarta are still not aware with the meaning of their cultural wealth. Besides that, it can be seen through the passion of foreigners to learn Javanese language that decreases along with the use of Javanese language by society. For the last years, foreigners who learn Javanese language in Wisma Bahasa are less than 5 people in a year. The interview result of Kompas at article Wisma Bahasa [14] with the director of Wisma Bahasa, Agus Soehardjono in Yogyakarta said that 599 foreigners that study at Wisma Bahasa, only 3 of them who chose to learn Javanese Language. 10 years ago, there will be 10-15 people, but as time goes on, the decreasing happens.

According to Ipung [15], there are several factors that cause the siltation of Javanese among young people: (1) Young generation factor. The young generation feels ashamed to use Javanese language in daily conversation in reason of Javanese language is old fashioned, hard, and also confusing. The ashamed feeling is also conducted by the circle of friendship that also feels ashamed to use Javanese language. (2) Family factor. Parents also take part in Javanese language development. Parents will teach their kids to speak Javanese language to avoid Javanese language from extinction. Unfortunately, the reality says that parents nowadays will likely teach their children to speak national language instead of their local language, or even they will teach their kids how to speak English for daily life. Most likely, parents will teach their kids to speak Indonesian but they will speak Javanese with their friends. If this habit continu ous, there will be no generation that can maintain Javanese language. (3) School Factor, the allocation of Javanese language classes in elementary school, middle school, and high school is just 2 hours per week. The truth that Javanese language has the same material as Indonesian language class and English class, and now some schools choose to not including Javanese language in their curriculum. In Surabaya, their government arranged the program 'One day with Javanese language'. Some private schools in Surabaya also responded that Javanese language class will burden their students more [16]. (4) Government factor. Government never really takes care of the activities that are related to maintaining Javanese language from extinction. The government also does not provide the Javanese language course facility, and the recruitment of Javanese language students also limited. This action is just like being supported by the society that thinks that using Javanese language will be known as primitive. Slowly but sure, Javanese language will be left by its own speakers. This will lead to the extinction of Javanese language in Java itself.

\section{Existing Solutions}

There are some solutions to keep Javanese language from extinction, ideas by Rahardjo [17] as follows: (1) Teach the kids from the beginning about Javanese language and culture. So, the kids will not think that Javanese language is old fashioned, so they will use Javanese 
language as their daily language to communicate with everyone. (2) Get used to use Javanese language as daily language. Using Javanese language as daily language correctly using the right rules so the kids will follow and Javanese language will stay exist because the increase of the speakers. (3) Teaching Javanese language formally or informally. Formally the Javanese language will be learned at school. Informally can be learned from family and society, so they will learn directly about Javanese language and culture as practical class from the class at school.

\section{Results of Finding Idea}

Based on Focus Group Discussion result, here are some ideas proposed to maintain Javanese language and the way to realize it:

1. Conducting "One day with Javanese language" just the same as "Rebo Nyunda" in Bandung, where the citizen is obligated to speak Sundanese language in Wednesday, in hope the future of Sundanese will be maintained and the strangers living in Bandung will be attracted to learn Sundanese, The realization of this program can also be named as for example "Senen Njowo", where the citizen has to use Javanese language throughout the day. So, this program could lead to the better development of Javanese language.

2. Making "Java Café". Café is one place that will be visited by a lot of students in Yogyakarta to do their assignments or just to hang out with their friends. The concept of Java café is just a small restaurant that will be all designed like old fashioned Javanese design. All the menus will be written in Javanese so the customer will learn more about Javanese. The café will not cost high to attract people to come. The café will provide the free Javanese language course and will be given $75 \%$ discount for people who successfully learn Javanese language by following the class and becoming the teacher for that free lesson class. This discount will attract more customers to come. The music that will be played in the café is those songs which the lyric is in Javanese language.

3. The selection of "Javanese language ambassador". Just like the other ambassadors, the Javanese language ambassador is the person who can maintain and introduce Javanese language. However, the ambassador will not be useful if the selection process is not effective. The selection of Javanese language ambassador needs to be judged by the ability to speak Javanese language, the caring to Javanese language, and also the ability of public speaking because an ambassador has to be able to introduce their task clearly. Here are some recommended steps of the selecting Javanese language ambassador: (a) The selection at regency level with requirements: Able to speak Javanese language at any level (both Padinan Javanese and Krama Inggil Javanese); 20-30 years of age, agreed to do all the task along the time being the ambassador. At this stage, the candidate will be facing an intelligent test. (b) Province selection. At this stage, the delegate will be facing the psychological test to see the leadership and their love for their country. (c) Final selection. At this stage, the candidate of Javanese language ambassador will be facing the art test. Where the delegate can choose singing, dancing, or drama in Javanese to be shown.

\section{Results of Prioritizing Idea}

Based on the FGD result, there are 3 criteria that will be used to prioritize ideas or alternatives, they are cost, infrastructure readiness, and the resource needed. The result of AHP using Super Decision software is shown in Figure 1 until Figure 6. 


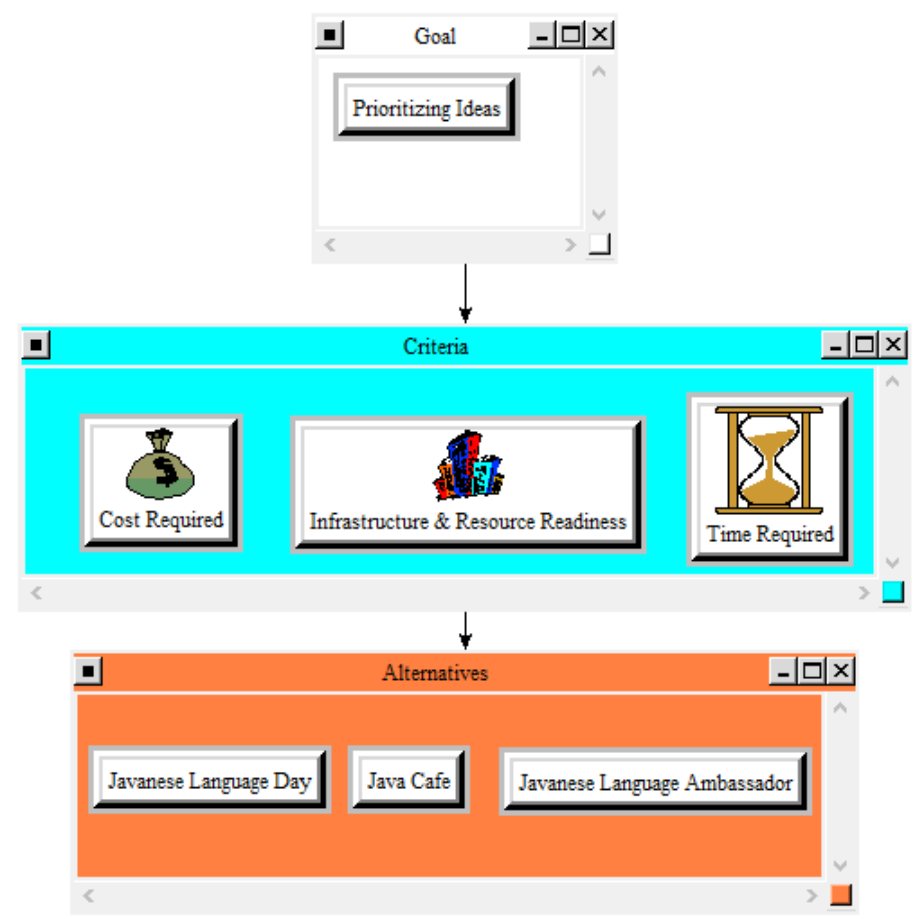

Figure 1. Decomposition result

\begin{tabular}{|c|c|c|c|c|}
\hline 1. Choose & 2. Node comp & arisons with respect to Prioritizing Ideas & \multicolumn{2}{|c|}{ 3. Results } \\
\hline Node Cluster & \multirow{3}{*}{\multicolumn{2}{|c|}{$\begin{array}{l}\text { Graphical Verbal Matrix Questionnaire Direct } \\
\text { Comparisons wit "Prioritizing Ideas" node in "Criteria" cluster } \\
\text { Infrastructure \& Resource Readiness is } 3.915 \text { times more important than Time Required }\end{array}$}} & Normal - & Hybrid - \\
\hline Choose Node $\mid \nabla$ & & & \multicolumn{2}{|c|}{ Inconsistency: 0.07402} \\
\hline Prioritizing $\mid \sim$ & & & Cost Requ & 0.24389 \\
\hline \multirow{2}{*}{ Cluster. Goal } & Inconsistency Infrastruc & Time Requi & \begin{tabular}{|l|} 
Infrastru $~$ \\
\end{tabular} & 0.63341 \\
\hline & \multirow[t]{2}{*}{ 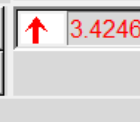 } & $\leftarrow 2.621$ & Time Requ & 0.12270 \\
\hline Choose Cluster $\Delta$ & & 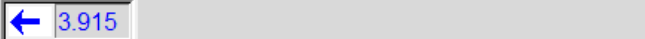 & & \\
\hline Criteria & & & & \\
\hline
\end{tabular}

Figure 2. Result of comparisons between criteria

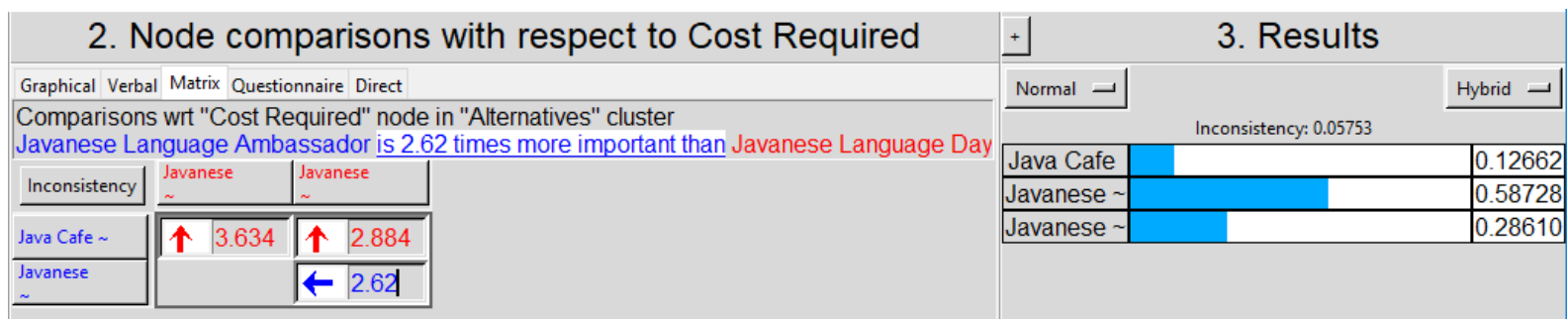

Figure 3. Result of comparisons between alternatives against cost required criteria

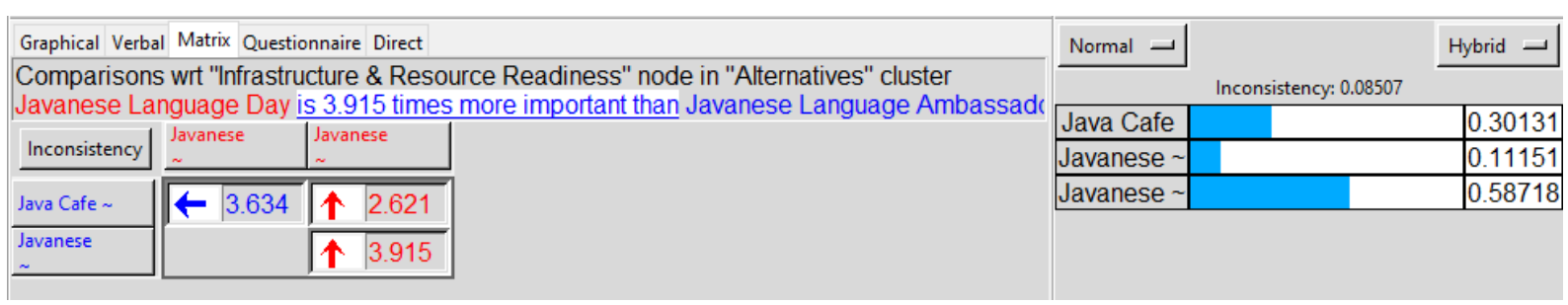

Figure 4. Result of comparisons between alternatives against infrastructure \& resource readiness 


\begin{tabular}{|c|c|}
\hline Normal - & Hybrid - \\
\hline \multicolumn{2}{|c|}{ Inconsistency: 0.08506} \\
\hline Java Cafe & 0.27370 \\
\hline Javanese & 0.09402 \\
\hline Javanese & 0.63228 \\
\hline
\end{tabular}

Figure 5. Result of comparisons between alternatives against time required

\begin{tabular}{|c|c|c|c|c|}
\hline Name & \multirow[t]{2}{*}{ Graphic } & Ideals & Normals & Raw \\
\hline Java Cafe & & 0.491982 & 0.255397 & 0.127699 \\
\hline $\begin{array}{l}\text { Javanese Language } \\
\text { Ambassador }\end{array}$ & & 0.434358 & 0.225483 & 0.112742 \\
\hline Javanese Language Day & & 1.000000 & 0.519119 & 0.259560 \\
\hline
\end{tabular}

Figure 6. Result of idea prioritizing

The result shows that all the pairwise comparisons are valid with inconsistency value $\leq 0.1$. Based on Figure 6, the result shows that the idea to be realized from the most to the least is one day with Javanese language, Java Café and the last is Javanese language ambassador.

\section{CONCLUSION}

The ideas that are submitted to maintain Javanese language in Yogyakarta based on the research are (1) 'One day with Javanese language'. (2) The making of 'Java Café' and (3) The selection of ' Javanese language ambassador'. Implementation to realize the ideas are divided into 3 ways, first, announce to society about the One Day With Javanese Language through media, second, providing land and do charity to make Java Café in a strategic place, third, selecting the Javanese language ambassador that is smart and care with Javanese language. Based on AHP, with the prioritize 1, 2 and 3, it is predicted that people will be attracted to learn Javanese language and sure the increasing of Javanese language speakers will happen based on expert judgment.

\section{ACKNOWLEDGEMENTS}

The authors thank the Universitas Islam Indonesia for helping with the funding of this research and for all the experts who provided advice and participation in this research.

\section{REFERENCES}

[1] P. Suwarna, Strategi Penguasaan Berbahasa, Adicita, Bandung, 2002.

[2] A. Chaer and L. Agustina, Sosiolinguistik: Suatu Pengantar, Rineka Cipta, Jakarta, 1995.

[3] Soeparno, Dasar-Dasar Linguistik, Mitra Gama Widya, Yogyakarta, 1993.

[4] Aminuddin, Pengantar Apresiasi Karya Sastra, Sinar Biru, Bandung, 1995.

[5] Kemendikbud, Badan Bahasa Petakan 652 Bahasa Daerah di Indonesia, https://www.kemdikbud.go.id/main/blog/2018/07/badan-bahasa-petakan-652-bahasadaerah-di-indonesia, 2018 (Accessed 12 December 2019).

[6] N. Sucahyo, Milenial Indonesia Kian Berjarak dengan Bahasa Ibu, https://www.voaindonesia.com/a/milenial-indonesia-kian-berjarak-dengan-bahasa-ibu14658380.html, 2018. (Accessed 12 December 2019).

[7] J. Collins, Keragaman bahasa dan kesepakatan masyarakat: pluralitas dan komunikasi, Jurnal Dialektika, (2014) 149-180.

[8] Kemendikbud, Frase Verba dalam Bahasa Jawa, Perpustakaan Pusat Pembinaan dan Pengembangan Bahasa, 1987. 
[9] N. Sucahyo, Milenial Indonesia Kian Berjarak dengan Bahasa Ibu, https://www.voaindonesia.com/a/milenial-indonesia-kian-berjarak-dengan-bahasa-ibu14658380.html, 2018. (Accessed 12 December 2019).

[10] Kompas, Motivasi Memakai Bahasa Jawa Makin Tiada, https://megapolitan.kompas.com/read/2009/04/02/01330946/motivasi.memakai.bahasa. jawa.makin.tiada?page=all., 2009 (Accessed 12 December 2019).

[11] N. Riza, Pembentukan Karakter melalui Pembelajaran Bahasa Jawa pada Siswa Kelas IV MI Maarif Giriloyo 1 Wukirsari Imogiri Bantul, Thesis, Fakultas Ilmu Tarbiyah dan Keguruan Universitas Islam Negeri Sunan Kalijaga, Yogyakarta, 2016.

[12] T. Saaty, How to make decision: the analytical hierarchy process, Europen Journal of Operation Research, (1990) 9-26.

[13] T. Saaty, Decision making with the analytic hierarchy process, International Journal of Services Sciences, (2008) 83-98.

[14] W. Bahasa, Minat Belajar Bahasa Jawa Menurun, http://www.wisma-bahasa.com/minatbelajar-bahasa-jawa-menurun, 2010 (Accessed 12 December 2019).

[15] Ipung, Pantang Malu Menggunakan Bahasa Jawa, http://www.ipung.blogspot.com, 2011. (Accessed 12 December 2019).

[16] Jawa Pos, Penerapan Hari Bahasa Jawa di Sekolah, Sekolah Khawatir Siswa Terbebani, http://jawapos.co.id/index.php?act=detail_c\&id=321062, 2008. (Accessed 10 December 2019).

[17] M. Rahardjo, Bahasa Jawa Krama, Pustaka Cakra, Jakarta, 2001. 